\title{
Cracking the Codes: Social Class and Gender in Annie Ernaux
}

Bethany LADIMER

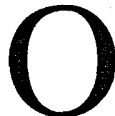

ver the past decade or more, feminist scholarship has produced an increasingly coherent discussion of how to consider gender and race together in literature and society. Social class, on the other hand, in the United States and elsewhere, remains to be investigated more thoroughly as it functions in conjunction with gender. In this article, I seek to clarify and expand the notion of social class and female sexuality as interdependent phenomena in the work of Annie Ernaux, as first recognized by Loraine Day who describes them as "fundamentally imbricated" in Les Armoires vides within an "interlocking network of social relations through which subjectivity is formed" $(43 ; 41)$. I hope to show that this inseparable relation between gender and class remains in place throughout Ernaux's increasingly autobiographical corpus, ${ }^{1}$ from the publication of Les Armoires vides in 1974 to her ninth book, Je ne suis pas sortie de ma nuit in 1997, and that it is central to Ernaux's project of understanding her identity and acquiring autonomy. I hope to illuminate further this association of class and gender by considering Ernaux's texts, particularly $\mathrm{La}$ Honte, through the lens of Pierre Bourdieu's sociological theory. This kind of reading seems almost to have been foreshadowed by Day, who refers to "a personal barometer for the measurement of social status" consisting of mannerisms, tastes, and speech (47), and by Nora Cotille- 
Foley, who refers to "socially encoded" female bodies (887). Bourdieu's model has the advantage of providing a clearer articulation between the categories of social class and gender as parts of a larger social field, while still distinguishing both of them from other categories.

In "Nothing to Declare: Identity, Shame, and the Lower Middle Class," which appeared in the special issue of the PMLA devoted entirely to the question of social class in January 2000, Rita Felski reflects on how little autobiographical literature has been written by former or actual members of the British lower middle class, and how little thought has been given to the improbability of self-disclosure by writers of this class origin. Felski emphasizes the persistent feeling of shame that produces this reluctance to speak about the past. While it is true that unlike other forms of identity, social class can be altered, and therefore has more contingency than race, gender, or sexual orientation, Felski rightly points out that class identity can be "a structure of feeling, a complex psychological matrix acquired in childhood ..." (38-39). ${ }^{2}$ Thus it is sometimes impossible to escape the shaming effects of early class domination even when a new class status has been achieved. This is especially true in cases of social mobility like Ernaux's, where her parents, particularly her mother, had managed to rise from the status of agricultural worker to proletariat, or working class, to become petit bourgeois owners of a small, family-run café-épicerie. Thus the humblest of French social origins was just a generation away, and as a child Annie received disturbing reminders of this on Sunday visits to relatives who remained ouvriers non-qualifiés or even ouvriers agricoles.

Ernaux's mother was intent on maintaining her new status and social respectability; the latter involved the appearance of prosperity, of course, but it was also often equated with sexual respectability for women, as the adolescent Ernaux discovered, which meant constant vigilance and restraint for girls who needed above all to distance themselves from certain bourgeois ideas of the easy virtue of working class women. The lower middle class, as Felski notes, thus "built the bars of its own prison" (36) by internalizing such strictures which denied them individual or collective pleasure, and yet it was also isolated from the bourgeoisie, which looked upon it with scorn. Felski notes that it is the very "in-betweenness" of this class, forever trapped uncomfortably between two others, and the impossibility of establishing a comfortable class identity of its own, that are at the heart of its lived reality (34). Key to this situation is the notion of shame as a sense of failure or lack in the gaze of another.

Although Ernaux's mother had risen in social stature by virtue of her individuality and initiative, she was paradoxically now bound by her new 
ethos to deny her daughter the expression of these very qualities. Annie Ernaux thus found herself in an even more "in-between" position than other members of her class, in that her mother provided a model of mobility even as she also embodied petit bourgeois values that impeded, for a while, her daughter's upward passage into the bourgeoisie. If Ernaux finally made that passage, in a further paradox, it was because of her mother's singularly intense reverence for learning and education, characteristics which although shared with the upper classes, are frequently encountered in a particular form in the petite bourgeoisie. Education represents the only aspiration possible for lower middle-class parents who have themselves little educational or cultural experience, and who therefore can only vaguely perceive the reality of the future life they endorse for their children.

In France, the national educational system has played an important role in ensuring some class mobility within a highly stratified society, but in practice, there are serious limits to how egalitarian the system actually is: a factory worker or other unskilled member of the labor force is no more likely to enter the university today than 30 or 40 years ago. ${ }^{3}$ The French community of higher education, broadly defined as inclusive of the university system and the Grandes Ecoles, is especially likely to reject the cultural values of the working class in everyday interaction if not in declared ideological and political position, and this is of course the reason that there are few intellectuals of such origin and why they have not felt comfortable engaging in the now widespread practice of writing the self. The few members of minority groups who do succeed within the educational system rarely turn against it to the extent of revealing the anguish of the shame it produces. In these respects, Annie Ernaux is doubly exceptional: she rose in social status and became a member of the teaching elite and one of the most widely read and appreciated French novelists today, but she also refused to turn her back on her past.

While Ernaux's insistence on and exploration of her class origins are considered troublesome and provocative by some critics (e.g. Plessy 246) it was the publication of Passion simple in 1992 that unleashed the first real storm of disapproval (Delorme 73; Laval 33; Frey 36). In this detailed account of a passionate sexual affair, Ernaux was taken to task for her impudeur, or shamelessness, and later for her focus on the body in her writing and for her affairs with men. But the same term has also been used against her for her more openly autobiographical descriptions of the physical realities of the spatially cramped and promiscuous, morally suffocating life of the lower economic classes in the 1940's and 1950's. As Lyn Thomas 
puts it, "Class, perhaps more than ever, is a taboo subject, and the person who raises it, in British or French social contexts, is likely to be accused of 'having a chip on their shoulder,' and to be required to find fresh inspiration" (152). Ernaux herself is willing to accept that she is provocative to the literary establishment. ${ }^{4}$ In addition to the consistent class and gender themes of her writing, she also alludes to a desire to write "en dessous de la littérature" as she puts it in Une Femme (23), searching for techniques that free her from the codified forms and rituals of high culture which belong in her view to those who have historically had material means of access to them, and rejecting entirely a certain romanticized representation of her class by a consecrated literary tradition (Les Armoires vides 117). Within the university in France, her writing has been greeted for the most part with silence, though scholars of French literature and language have paid more serious attention to her in the English-speaking world.

Yet several French sociologists have taken careful note of Ernaux's work, including Gérard Mauger, who concludes that it is as close to sociology as to literature (Mauger 44). Ernaux's own frequent references to the collective origin of individual identity, and passages like "Ne pas me contenter non plus de lever et transcrire les images du souvenir mais traiter celles-ci comme des documents qui s'éclaireront en les soumettant à des approches différentes. Etre en somme l'ethnologue de moi-même" (La Honte 40) further legitimize a critical approach that relies on sociological categories of analysis together with a consideration of Ernaux's literary strategies. In the manner of a sociologist, Ernaux offers a wealth of concrete description of everyday, material conditions that is unavailable in other French texts by working-class women writers (e.g. Claire Etcherelli, Christiane Rochefort). In those works by Ernaux that treat her milieu of origin, either fictionally or autobiographically, she constantly returns to the same humble Norman décor and set of people and events. Elsewhere, as in her descriptions of contemporary life in the Paris area in Journal du dehors, Ernaux is equally committed to repeated descriptions of a limited number of situations: beggars, vagrants, and homeless people in the métro or on the street, cashiers in their power relations with employers or the public, graffiti, displays of wealth or humiliating lack thereof in butcher shops, etc.

This level of concrete detail suggests particular analogies with the work of the French sociologist Pierre Bourdieu, as I indicated above. Toril Moi proposes Bourdieu's work, especially Sociology in Question and Distinction, as a possible tool for feminist analysis and critique, stressing that her "appropriation" of Bourdieu's work is not primarily motivated by 
the originality of his theories or their transcendence, which remain to be studied, but rather by the attention he pays to the interpretation of the commonest details of everyday life (What is a Woman 268). Briefly, Bourdieu offers a concept of a society, such as post-war France, as a "field": "By 'field,' I mean an area, a playing field, a field of objective relations among individuals or institutions competing for the same stakes." Within a social field, an internalized set of rules governs the behavior of the players. The goal at all times is to gain "legitimacy," to rule the field. Moi describes "legitimacy" as "the right to speak" (271), which is invested in "those agents recognized by the field as powerful possessors of capital" (271). The entire field censors those who do not have legitimacy by means of discourse, or coded language, which is always a form of "symbolic violence" and which is experienced as such by those who lack significant capital. Most of these transactions occur at the level of concrete detail in the conditions of everyday life, and in the choices made by an individual in personal style, values, and consumption. They are sometimes, but not always, expressed in words.

Ernaux's work refers to these concepts of social violence and social legitimacy in several ways. The notion of social violence is clearly present in her recurrent descriptions of the painful way in which both social class and gender relations revealed themselves to her in terms of fixed but veiled codes, which are themselves determined by those who have legitimacy. Emaux's young women characters and herself in the later works engage in an extensive project of deciphering or decoding, in their attempt to avoid the violence exerted on those who, like themselves, are unfamiliar with socially approved ways of speaking and acting. They refer explicitly to this difficult task from Les Armoires vides through La Honte, despite differences in emphasis. The private school provides the first encounter with symbolic violence “ 'Hier soir le père Leduc était tellement saoul qu'il est tombé sur le trottoir, qu'il a dormi sur sa bouteille.' La maîtresse se fige ... Elle a changé tout de suite de conversation, la maîtresse, ce que je vivais ne l'intéressait jamais ... toujours de mauvais goût" (61).

After the age of twelve, the code of sexual conduct and success becomes increasingly important: "Effarant ce que (Brigitte) connaissait le code ... Je me suis mise à employer les étranges mots de Brigitte ... Ne pas leur répondre, tu auras l'air de les encourager, elle m'apprend à vivre, Brigitte, le code encore et toujours" (La Femme gelée 68-70). Even when Ernaux has become a mature woman, she continues to regard individual behavior, including her own, as the enactment of a highly organized system of signs. Thus is Passion simple, her lasting interest in a passionate love 
affair which had no lasting meaning in itself is partially explained by the interpretation of the passion as a "text" through which she made sense of all the details of her existence during a certain period of her life, for which she was severely criticized by others, and which was eventually replaced by other texts (69). Of course the entire narrative strategy of La Honte consists of first re-establishing the codes, linguistic and other, that defined her at age twelve, which she sees as the only way to retrieve the girl she had been: "Mettre au jour les langages qui me constituaient, les mots de la religion, ceux de mes parents liés aux gestes et aux choses, des romans que je lisais ... me servir de ces mots, dont certains exercent encore sur moi leur pesanteur, pour décomposer et remonter ... le texte du monde où j'ai eu douze ans et cru devenir folle" (40). In this passage and throughout the book, Ernaux actually performs a social analysis of her own life that allows her to be increasingly objective and inclusive of others even as she sharpens her focus on her individual, subjective account. Her primary strategy is to "refuse the distinction between 'high' or 'significant' or 'low' or 'insignificant' matters," but rather consistently to link the two (Moi 268), and thus La Honte provides perhaps the best example of the congruence of her vision of society and that of Pierre Bourdieu.

La Honte was published in 1997 and constitutes a return in fully autobiographical form to the material of the first five of Ernaux's works: an only daughter of small grocery-café owners in the region between Rouen and Le Havre in the 1940's and 50's. It opens with a confession that Ernaux's father tried to kill her mother one Sunday in June, 1952, and that this particular story has never been written before. While this may be literally true, readers of Ernaux are familiar with the advent of both social shame and sexuality at age twelve, and with the idea that a determining event occurred at this time (presented variously as the arrival of a first boyfriend, as in Ce qu'ils disent ou rien, or as the narrator's perception of her drunken aunt in the street, a reminder of her family's class origins that initiated her into social shame (Une Femme 35), or as a more gradual process involving school, as in Les Armoires vides). The reader also knows that this determining event is responsible for Ernaux's career as a writer, a claim that is reiterated in La Honte. Thus I read in the opening revelation a "central fabula," or "matrix of fabulation," that unites and sheds light retrospectively on all of Ernaux's narratives, not only in terms of the event described, but more importantly in terms of the breaking down and rewriting of class and gender codes that oppressed Ernaux. La Honte also provides many important clues to the relationship between the class and gender in Ernaux's corpus. 
At this point, before investigating the details of Annie Ernaux's particular case, it may be useful to clarify my conceptualization of class and gender as they operate together. Turning again to Toril Moi's investigation of Bourdieu's work as a possible framework for a feminist analysis, we find that Moi speculates on a possible relationship between class and gender that remains faithful to Bourdieu's own notions (though he does not directly address this question). In Distinction, he comes very close to defining the notion of gender as a particularly "combinatory" social category, one that infiltrates and influences every other category (105-106). This concept of gender has much in common with social class as discussed elsewhere by Bourdieu (Moi, 288). Social class, like gender, would each be part of what Bourdieu calls the "whole social field," rather than fields in themselves and Moi endorses this idea because it allows us to consider both gender and class together "without specifying a fixed and unchangeable hierarchy between them" (289). One is not more important than the other, and both are extremely variable entities which are especially "combinatory" with each other, so that they are very often experienced together. This is in fact a more complex statement than most materialist concepts of femininity, in that it actually means there is no such thing as "pure gender capital...the capital at stake is always the symbolic capital relevant for the specific field under examination" (Moi, 291). Femininity in Ernaux's texts, fictional or autobiographical, can only be fully understood when it is apprehended together with social class suffering and striving.

In Ernaux's case, and I would speculate that this is frequent among women writers, class and gender are linked by the body, in that more than other markers of place within the whole social field they are exhibited in literature through the appearance and behavior of the body. Ernaux has clearly broken new ground in her depictions of bodily and sexual reality, in both health and illness and youth and age. Much of what has been considered "provocative" in her writing is immediately traceable to these presentations of the female body. Lyn Thomas points out the importance in Ernaux's work of the gaze, and in particular of mirrors, relating them to her internalization of the critical gaze of middle-class observers (76). It is also interesting to watch the evolution of these feelings of shame when the narrator catches sight of herself in a mirror. In early childhood, before her experiences had led her to internalize a sense of her inferiority, she liked to look at herself in the mirror (Les Armoires vides 65). Later in life, when she has assumed her origins and her sexuality (and her own autobiographical voice) in what amounts to a position of pride, she will 
return to the role of the one who looks and refuses to be looked down upon ( Je ne suis pas sortie de ma nuit 17). In between, the shame that occurs at the sight of herself most often refers both to gender and to class, as in Les Armoires: "La vitrine de nouveautés, la glace inattendue, et je me découvre, mal coiffée, le rire large, la bouche vicieuse, presque mauvais genre...je marchais comme ma mère et mettais ma main devant ma bouche pour rire comme les filles du quartier"(126).

The threatened attempt at murder paradoxically caused a breakdown of meaning and the impossibility of expressing what had happened, as Ernaux immediately suggests after the account, by explaining: "A quelques hommes, plus tard, j'ai dit: 'Mon père a voulu tuer ma mère quand j'allais avoir douze ans.'Avoir envie de dire cette phrase signifiait que je les avais dans la peau. Tous se sont tus après l'avoir entendue. Je voyais que j'avais commis une faute, qu'ils ne pouvaient recevoir cette chose-là"' (16). In this passage, the stakes are both pleasing a man she desires, and speaking about subjects considered worthy of attention by the bourgeoisie, but both were impossible in view of her subject matter. She had first to invent a language in which to tell this event and be listened to (17), and this also involved altering the stakes of her discourse. The "scene" is thus a sort of fatal catalyst that reveals the inadequacy of both languages then known to Ernaux: the antiseptic, pretentious language of her bourgeois school, and the rudimentary, material language of her home in which "il n'y avait presque pas de mots pour exprimer les sentiments" (74). Until this point, the inadequacy of each language or code had been invisible to her, but now, after her "fall," she realized that these two systems of representation, both of which imprisoned and stifled her (115), though for quite different reasons, could no longer account for her reality, precisely because the social shame implicit in it couldn't be talked about in either one. Ernaux then began to investigate the codes that were imposed on her, and also to invent a new, differentiated self, for if her scholarly ability (which Bourdieu would call "intellectual capital") could still guarantee her scholarly success, it was suddenly clear that it could not repair her social shame. The way was opened to her emerging sexuality to assume a primary role in her social assent by providing a different kind of capital. The natural adolescent recreation of self then took on this added dimension.

In the arduous passage between the lost sensuality of childhood and the authorial voice and gaze she eventually won, it is not surprising that the shame over her own body and class situation developed in the fiction as a gradually revised vision of her mother's body. Even as a child, Ernaux identified her mother's appearance as different from the socially approved 
norm: "Je dédaignais les squelettes élégants des catalogues, cheveux lissés, ventre plat, poitrine voilée. C'est l'explosion de chair qui me paraissait belle, fesses, nichons, bras et jambes prêts à éclater dans des robes vives qui soulignent, remontent, écrasent, craquent aux aisselles" (Les Armoires vides 24). As she grows away from her mother, she recalls the afternoons spent taking a nap against her mother's back and how beautiful she found her. In $\mathrm{Ce}$ qu' ils disent, this memory is rejected violently by the fifteen year old girl along with her mother's entire way of life (61); in Une Femme (96) and Je ne suis pas sortie de ma nuit (26), the sight of her aged mother's sleeping body moves her once again to tears.

In La Honte, the internalization of the middle-class gaze by the young Ernaux is dramatized in a scene that follows the opening scene of attempted murder. The daughter is returning late at night from a school outing, accompanied by her teacher and some other girls. The mother comes to the door in her nightdress in a passage that shows the first inscription of the daughter's social and gendered shame in the mother's body, publicly exposed:

. . . ma mère est apparue dans la lumière de la porte, hirsute, muette de sommeil, dans une chemise de nuit froissée et tachée (on s'essuyait avec, après avoir uriné). Mlle L. et les élèves ... se sont arrêtées de parler... Je venais de voir pour la première fois ma mère avec le regard de l'école privée. Dans mon souvenir, cette scène, qui n'a aucune commune mesure avec celle où mon père avait voulu tuer ma mère, $m$ 'en paraît le prolongement. Comme si à travers l'exposition du corps sans gaine, relâché, et la chemise douteuse de ma mère, c'est notre vraie nature et notre façon de vivre qui étaient révélées. (117)

After a trip to Lourdes with her father, which is also a voyage of initiation into social inferiority and shame, she says "A la limite je ne percevais plus (la honte), elle était dans le corps même" (140). Shame over her mother's body has passed into her own. ${ }^{6}$

In this family, it is also the mother who encourages her daughter towards upward social mobility, both by her own dissatisfaction with her lot, and by her concern with speaking better French. Though both Ernaux's parents were themselves born to parents who spoke only Norman patois and the father was indifferent to "le beau parler," her mother was eager to try new expressions that belonged to the bourgeoisie. She followed her daughter's schoolwork closely, asked to be corrected, read her books, and 
took her to museums. The father spent his time puttering in his garden and around the house. This apparent reversal of some gender roles was empowering to the daughter, at least in some of the texts. In La Femme gelée, which has been seen as a novel of a negative apprenticeship (Thomas 10 ), the only viable alternative to bourgeois femininity is provided by the mother, the only woman who managed to be less submissive and more active and autonomous than the bourgeois norm and not find herself alone. Imitating her, of course, at least in the terms of the story, would preclude upward social mobility by means of marriage into the bourgeoisie, as the adolescent character notes in her shame when her friend Brigitte inquires mockingly into the roles played in the house by the two parents (75). At the end, the daughter leaves home and begins little by little to change her official class identity. It is only with the writing of La Place and Une Femme, in 1984 and 1987, that Ernaux began a return to acceptance of her mother and their social class, an acceptance that appears complete at the publication of Je ne suis pas sortie de ma nuit in 1997.

The daughter succeeds in all the fictional narratives of Yvetot (Les Armoires vides, Ce qu'ils disent ou rien, La Femme gelée) in having sexual experiences with boys of a higher social situation which bring her pleasure, a sense of freedom from her social inferiority, and finally the pain and "social violence" of learning the harsh code of prescribed feminine sexual conduct. These three early works each in its way trace a downward spiral in the development of the woman. In her later works, Ernaux revises this portrayal of sexuality to some extent, though sexuality is never without reference to issues of class.

For the young protagonists, Bourdieu's notion of gender capital as a variable element in acquiring "social capital" (which includes all the others and surpasses them) seems very much at work. In their pursuit of boys of higher social standing who are continuing their education rather than working at menial jobs, the girls agonize about appearing to belong to the boys' social class. A moment of triumph is expressed in terms that recall the concept of "distinction" or taste as the most infallible of social markers: "Un jour, enfin, un garçon de collège a dit de moi 'vachement relaxe, cette fille' ... Relaxe, ça ne se dit pas des péquenaudes, des pouffiasses ... Il m'avait fallu presque deux ans pour arriver à ma gloire, ... parler l'argot des collégiens, connaître des Platters, Paul Anka et l'Adagio d'Albinoni" (Les Armoires 127).

At first, all three experience a discovery of heterosexual pleasure and acceptance by their new milieu; in fact, the two are inseparable. The entire narrative of Ce qu' ils disent ou rien, which covers three months in the life 
of a fifteen year old, is structured around a tension between Anne's family on one hand and her discovery and desire for sexual experience on the other. Returning from her lovemaking with a boy, Denise reflects that real happiness was this shameless freedom to be Denise Lesur without caring what anyone from her school thought of her (138). This sense of class liberation, like her physical pleasure, could only have been conferred on Denise by a boy she regards as superior, and on the next page she says this could have been any such boy, without reference to his other characteristics (139).

It does not take long for the full truth of the relationship between class and gender to reassert itself. "Qui m'aurait appris ce truc de bourgeois, la pudeur. Encore le genre de choses que je ne pouvais pas deviner, ça se passe en secret, un code intérieur," says Denise (130). Later, in the highly eroticized atmosphere of the library of the Sorbonne, she meets the student of cultured background who will ultimately get her pregnant and desert her, to whom she yields because he seems so much her superior (170). The narrator of La Femme gelée reminds the reader that the codes of gender and class often function in the same inegalitarian way, even at the Sorbonne where the creation of the literature of the educated classes is compared to an ejaculation $(90,96,108)$. Anne in Ce qu'ils disent ou rien presents an ironically nuanced version of this disillusionment, in that her boyfriend Mathieu, a student from Paris, is officially a Marxist and tells her about the oppression of her people through their lack of education. When she suffers a cruel rejection from him, she says "Le plus atroce, avoir cru entrévoir la liberté avec eux, ils disaient c'est malsain d'être vierge, et la société est à détruire, je l'ai vue la liberté...Ils avaient des règles aussi, je ne les connaissais pas (123). Anne is left with a sense of having been betrayed by both the norms and values of her mother and of the bourgeoisie, into which she had gained brief acceptance through her gender.

In Les Armoires vides and La Femme gelée, as in Ernaux's own early adult life, this sense of double betrayal and alienation is well developed. When the project of social advancement by means of gender and educational capital has been realized, the bourgeois code of femininity turns out to be more oppressive in its own way than the gender code of the lower class. Although Ernaux's characters often enlist their sexuality to good effect in their attempt to free themselves of the fate reserved for them by their original milieu, a newly achieved femininity within a new social setting is not presented as a guarantor of individual freedom either, in that such an identity also belongs to a highly codified social space and requires still more negotiation if a personal identity is to survive at all. The 
narrator in La Femme gelée marries a graduate of one of the Grandes Ecoles and follows him on his work assignments, increasingly confined by the raising of their children and gradually renouncing her own career aspirations. With the birth of her second child, she realizes her life is essentially over. In Les Armoires vides, Denise concludes the book in a startling revelation that she understands the terms of the complicated social violence of which she has been a victim, and that her abortion, hitherto regarded as the realization of her mother's prediction of her fundamental guiltiness, is also a capitulation to the class culture of her boyfriend (182).

In La Honte, a more openly autobiographical work, the narrative of events that will define the individuality of Ernaux's character as distinct from the account of the social forces that determined her begins when the book is three-quarters over. Contemplating again the photos of herself at age twelve, she reaffirms that social shame still unites her with them, but that the advent of sexuality two years later in fact separates her from her former self: "C'est (la honte) seulement qui fait de cette petite fille et de moi la même, puisque l'orgasme où je ressens le plus mon identité et la permanence de mon être, je ne l'ai connu que deux ans après"(142). Sexuality not only separates her from her origins, as it did for her fictional characters, but also creates her individuality, as it was not able to do for them. Ernaux gives evidence of this in Passion simple, which shocked critics as the deeply sensual confession of a woman in her late forties. Ernaux's passion for "A." is lived out in the relative impersonality of a modern Paris suburb, after her divorce and when her children are grown, in the somewhat defiant professional identity as she has defined with respect to the rest of the French intelligentsia. She feels a "profound satisfaction" in remembering the women of her neighborhood in Yvetot who spent the afternoon with a lover, and who were humiliated by their milieu because they were behaving badly (30). Ernaux is well aware that she has arrived at a social situation that enables her to live out her pleasure in peace, and that the pleasure of her passion could only occur outside the censorship of both of the class ideologies - working class and bourgeois - she has left behind.

Yet Ernaux's individuality is not to be confused with individualism. One great paradox of all of Ernaux's writing is that she arrives at an understanding of her own individuality by studying in detail the codes or doxa of her own class and of the entire social field of which that class is a part. In Journal du dehors, there are unifying themes among the fragments and repetition of certain social situations and occurrences, and a strong subjectivity emerges from the purportedly "objective," "fragmented" 
accounts. Here, the reader is struck by the degree to which she reveals her personal class-consciousness, for example, which has become a social and political stance with respect to the dominant class. In the last paragraph she explains the continuousness of individual identities. We are all part of a whole; her identity is porous (107). For Ernaux, "speaking as" will always be "speaking for." In the end, Ernaux's personal identity is not imaginable outside her connection to her community, and solidarity with her past is her deepest comfort in the dominant milieu into which she has emigrated.

Middlebury College 


\section{Notes}

1. In the discussions that follow, I will be treating the fictional characters from Ernaux's first three works as though they exist in a continuum with the young Annie Ernaux the woman, as she is eventually revealed in Une Femme, La Place, and La Honte. Following Nancy K. Miller in " Writing Fictions: Women's Autobiography in France" in Life/Lines: Theorizing Women's Autobiography, I use a "dialectical process of reading," a "double reading," of autobiography with fiction. This seems to me to be all the more justified in that Ernaux is highly sensitive in her writing to the risks of going public with her personal experiences, i.e. of autobiography, and also because in her recent work La Honte, Ernaux provides a selfdeclared autobiographical account of much of the material that had already appeared in earlier works.

2. Felski cites Carolyn Steedman, Landscape for a Good Woman. London: Virago, 1985. I refer here and throughout to the structures and classifications of French society referred to as "groupes socioprofessionnels" by E. and H-L Knox in their textbook on French civilization, Plus Ça Change, Paris: Hatier-Didier 1987. This classification is the one most often used in sociological research, the press, and official governement statistics. It differs from the marxist description of the proletariat and the bourgeoisie, although the latter term remains a convenient way to refer to people of comfortable financial status. In general, where Rita Felski refers to a member of the "lower middle class" in the case of Britain, the French equivalent would be "petit bourgeois," or in keeping with the Knox's definition "petit commerçant."

3. Christian Baudelot, lecture delivered at Middlebury College, March 31,2000 .

4. Ernaux has experienced much of the same incomprehension and hostile reaction as Simone de Beauvoir on the publication of The Second Sex in 1947: critics attempt to "disqualify" Ernaux as a serious writer or intellectual, and their discourse often focuses on Annie Ernaux the person or the woman, rather than the writer. For an analysis of the reception of The Second Sex, see Toril Moi, Simone de Beauvoir 78.

5. Germaine Brée coined this term, in "George Sand: The Fictions of Autobiography." Nineteenth Century French Studies 4 (1976): 438-49.

6. The young girl (Une Fenme 63) and later the mature writer (Je ne suis pas sortie 77) are aware in general of their profound resemblance to the woman whose gestures and voice are sometimes embarrassingly loud and violent, and who thinks in "paroles abruptes" (Une Femme 51). The 
mother's outbursts of frustration and anger refer precisely to the limitations of her social condition, just as they do for the daughter. One can even speculate that the mother's brusque manner of speaking, shouting, laughing, and even drinking have marked the daughter's writing, which is also brusque and often transgressive in its subject matter, and thus often imitates this oral tradition. This may seem at first glance to contradict Warren Motte's hypothesis in "Annie Ernaux's Understatement" (56), that Ernaux adopts here mother's characteristic understatement or "meiosis" as her primary literary device. Motte cites the Oxford English Dictionary definition of meiosis: "A figure of speech by which the impression is intentionally conveyed that a thing is less in size, importance, etc. than it really is." Certainly this applies to the mother's verbal utterances, but it seems to me that it is precisely the coexistence of these minimal sentences and the brusque emphasis of her tone and manner that create the strange power of the mother's speech and of her daughter's literary style. 


\section{Works Cited}

Bourdieu, Pierre. Distinction: A Social Critique of the Judgement of Taste. Cambridge: Harvard UP, 1998. Trans. Richard Nice.

Cotille-Foley, Nora. "Abortion and Contamination of the Social Order in

Annie Ernaux's Les Armoires vides." The French Review 72.5 (1999): 886-896.

Day, Loraine. "Class, Sexuality, and Subjectivity in Annie Ernaux's Les Armoires vides." Contemporary French Fiction by Women: Feminist Perspectives. Eds. Margaret Atack and Phil Powrie. Manchester: Manchester UP, 1990. 41-55.

Delorme, Marie-Laure. "Annie Ernaux sans surprise." Le Magazine Littéraire 351 (February 1997).

Ernaux, Annie. Les Armoires vides. Paris: Gallimard Folio, 1974.

-. Ce qu' ils disent ou rien, Paris:Gallimard Folio, 1977.

- La Femme gelée, Paris: Gallimard Folio, 1981.

-. La Place, Paris: Gallimard, 1984.

-. Une Femme, Paris: Gallimard, 1988.

-. Passion simple, Paris: Gallimard, 1992.

- Journal du dehors, Paris: Gallimard, 1993.

- La Honte, Paris: Gallimard Folio, 1997.

—. "Je ne suis pas sortie de ma nuit," Paris: Gallimard, 1997.

Felski, Rita. "Nothing to Declare: Identity, Shame, and the Lower Middle Class." PMLA 155.1 (2000): 133-145.

Frey, P. "La Vie d'Annie Ernaux n'est pas gaie." Elle (February 3, 1997). Holmes, Diana. French Women's Writing 1848-1994. London: Athlone, 1996.

Laval, M. "Ce jour-là, le 15 juin 1952.” Télérama (January 15, 1997).

Mall, Laurence. "Moins Seule et Factice: La Part Autobiographique dans Une Femme d'Annie Ernaux." The French Review 69.1 (1995): 45-54. Mauger, Gérard. "Les Autobiographies littéraires: objets et outils de recherche sur les milieux populaires." Politix 27.

Miller, Nancy K. "Writing Fictions: Women's Autobiography in France." Life/Lines: Theorizing Women's Autobiography. Ithaca: Cornell UP, 1988.45-61.

Moi, Toril ,What is a Woman? And Other Essays. Oxford: Oxford UP, 1999.

-. Simone de Beauvoir: The Making of an Intellectual Woman. Oxford: Blackwell, 1994.

Motte, Warren. "Annie Ernaux's Understatement." The French Review 69.1 (1995): 55-67. 
Plessy, B. “Annie Ernaux est-elle un cas?" Le Bulletin des Lettres 561 (March 1997).

Thomas, Lyn. Annie Ernaux: An Introduction to the Writer and her Audience. New York: Berg, 1999.

Tondeur, Claire-Lise. "Entretien avec Annie Ernaux." The French Review 69.1 (1995). 37-44. 